\title{
The Anti-Inflammatory Effects of Glucagon- Like Peptide Receptor Agonist Lixisenatide on the Retinal Nuclear and Nerve Fiber Layers in an Animal Model of Early Type 2 Diabetes
}

Yeon Woong Chung, ${ }^{*}$ Jae Hyung Lee, ${ }^{\dagger}$ Ji Young Lee, ${ }^{*}$ Hyun Hee Ju, ${ }^{\ddagger}$ Ye-Jee Lee, ${ }^{\S}$ Dong Hyun Jee, ${ }^{*}$ Seung-Hyun Ko, ${ }^{\S}$ and Jin A Choi*

From the Department of Ophthalmology and Visual Science, ${ }^{*}$ the Clinical Research Center, ${ }^{\ddagger}$ and the Division of Endocrinology \& Metabolism, ${ }^{\S}$ Department of Internal Medicine, St. Vincent's Hospital, College of Medicine, The Catholic University of Korea, Seoul; and the Department of Ophthalmology and Visual Science ${ }^{\dagger}$ St. Mary's Hospital, College of Medicine, The Catholic University of Korea, Seoul, Republic of Korea

\author{
Accepted for publication \\ January $17,2020$. \\ Address correspondence to Jin \\ A Choi, M.D., Ph.D., Depart- \\ ment of Ophthalmology, Col- \\ lege of Medicine, St. Vincent's \\ Hospital, The Catholic Univer- \\ sity of Korea, Jungbu-daero \\ 93th, Paldal-gu, Seoul, 16247, \\ Republic of Korea. E-mail: \\ jinah616@hanmail.net.
}

\begin{abstract}
This study explored the anti-inflammatory effects of a glucagon-like peptide-1 receptor agonist (GLP-1RA), known as lixisenatide, on the eyes of early type 2 diabetic mice. Diabetic $(d b / d b)$ mice were divided into three groups: GLP-1RA [lixisenatide (LIX)], insulin (INS) with controlled hyperglycemia based on the glucose concentration of lixisenatide, and diabetic control (D-CON). Nondiabetic control mice $(\mathrm{db} / \mathrm{dm})$ were also characterized for comparison. After 8 weeks of treatment, mRNA levels of inflammatory markers, terminal deoxynucleotidyl transferase-mediated dUTP nick-end labeling, immunohistochemical staining; Western blot of glial fibrillary acidic protein (GFAP) and thioredoxin-interacting protein; and retinal thickness were assessed in the central and peripheral neurosensory retina. LIX showed decreased immunohistochemical staining for both thioredoxin-interacting protein and GFAP in the central and peripheral neurosensory retina compared with D-CON and INS, and decreased expression of these proteins in the neurosensory retina and immunohistochemical staining in the optic nerve head for GFAP compared with D-CON. The inner nuclear layer in the peripheral retina in LIX was only thinner than those of D-CON and INS. In an early type 2 diabetic mouse model, lixisenatide treatment showed superior antiinflammatory effects on the retina and optic nerve head independent of hyperglycemia. Thus, the neuroprotective effects of lixisenatide treatment in the peripheral inner nuclear layer should be evaluated in early type 2 diabetic retinopathy. (Am J Pathol 2020, 190: 1080-1094; https:// doi.org/10.1016/j.ajpath.2020.01.011)
\end{abstract}

Type 2 diabetes (T2D) is caused by $\beta$-cell dysfunction in the pancreas in response to the increased insulin demand of nutrient overload or obesity-associated insulin resistance. ${ }^{1}$ The role of $\beta$-cells in the pathogenesis of diabetes has remained controversial. However, many studies have shown that hyperglycemia and inflammatory cytokines cause endoplasmic reticulum stress, the accumulation of reactive oxygen species, and eventually, $\beta$-cell dysfunction, and apoptosis. ${ }^{2}$ Moreover, oxidative stress plays an important role in diabetic vascular complications. ${ }^{3}$
Diabetic retinopathy (DR), one such diabetic vascular complications and the most common cause of visual deterioration in adult populations, ${ }^{4}$ had been considered a microvascular complication induced by hyperglycemia. However, several studies have shown that inflammation is

\footnotetext{
Supported by the Basic Science Research Program through the National Research Foundation of Korea (NRF) funded by the Ministry of Education grants NRF-2016R1A2B4008487 and 2016R1A6A1A03010528 (S.-H.K.); and the development fund of Catholic Institute for Visual Science of 2019 grant 5-2019-B0001-00242 (J.A.C.)
}

Disclosures: None declared. 
Table 1 Sequences of Forward and Reverse Primer Sets Used in qPCR

\begin{tabular}{|c|c|c|}
\hline Amplification & Forward primer & Reverse primer \\
\hline GS & $5^{\prime}-\mathrm{GCTGCAAGACCCGTACCCT-3^{ \prime }}$ & $5^{\prime}-$ TTCCACTCAGGTAACTCTTCCACA-3' \\
\hline GFAP & $5^{\prime}$-GAGTACCACGATCTACTCAAC-3' & $5^{\prime}$-CCACAGTCTTTACCACGATGT-3' \\
\hline TNF- $\alpha$ & $5^{\prime}-\mathrm{ATGAGCACAGAAAGCATGA}-3^{\prime}$ & $5^{\prime}-$ AGTAGACAGAAGAGCGTGGT-3' \\
\hline VEGF & $5^{\prime}$-CACAGCAGATGTGAATGCAG-3' & 5'-TTTACACGTCTGCGGATCTT-3' \\
\hline TXNIP & 5'-CGAGTCAAAGCCGTCAGGAT-3' & $5^{\prime}-$ TTCATAGCGCAAGTAGTCCAAAGT-3' \\
\hline GAPDH & 5'-CATGGCCTCCAAGGAGTAAGA-3' & 5'-GAGGGAGATGCTCAGTGTTGG-3' \\
\hline
\end{tabular}

GAPDH, glyceraldehyde-3-phosphate dehydrogenase; GFAP, glial fibrillary acidic protein; GS, glutamine synthetase; qPCR, quantitative PCR; TNF- $\alpha$, tumor necrosis factor alpha; TXNIP, thioredoxin-interacting protein; VEGF, vascular endothelial growth factor.

an important player in the progression of DR..$^{5-7}$ Villarroel et $\mathrm{al}^{5}$ reported that retinal neurodegeneration was present before any microcirculatory abnormalities, which may be used to develop novel therapeutic targets in the early stages of type $2 \mathrm{DR}$. Barber et $\mathrm{al}^{7}$ also reported that neuronal function may be compromised prior to apoptosis, contributing to an early deterioration of vision in type 2 DR. These results suggest that blocking inflammation in the eyes in early T2D may decrease neuronal dysfunction and thus reduce vascular complications caused by type $2 \mathrm{DR}$.

Recent studies have shown that thioredoxin-interacting protein (TXNIP) is an important component in both T2D and type 2 DR. TXNIP binds to the redox-active cysteine residues of thioredoxin, inhibiting its oxidoreductase activity, linking this endoplasmic reticulum stress to inflammation, and resulting in target organ dysfunction. ${ }^{8-10}$ TXNIP is known to be highly expressed in the ganglion cell layer, internal plexiform layer, internal nuclear layer (INL), retinal endothelial cells, Müller cells, and pericyte cells in the retina, as well as human islet cells, under hyperglycemic states. ${ }^{1-14}$ TXNIP increases metabolic dysregulation, including hyperglycemia, oxidative and endoplasmic reticulum stress, and inflammation. ${ }^{9,10,15-18}$ In addition, TXNIP up-regulation leads to $\beta$-cell apoptosis in $\mathrm{T} 2 \mathrm{D},{ }^{19-22}$ and angiogenesis in type 2 diabetic retinas by promoting vascular endothelial growth factor A (VEGFA), also known as vascular endothelial growth factor (VEGF), which is one of the most important players in the pathogenesis of proliferative DR. ${ }^{12,18,23}$

Insulin, which is important for the treatment of T2D, suppresses TXNIP expression in $\beta$-cells by decreasing hyperglycemia and its induced oxidative stress. ${ }^{19,21,22,24,25}$ However, insulin has adverse effects such as weight gain and hypoglycemia, as well as increased vascular permeability causing an edematous state after the initiation of intensive insulin therapy. ${ }^{26-28}$ In a diabetic rat model, Bixler et $\mathrm{al}^{29}$ concluded that several genes associated with inflammatory processes, microvascular integrity, and neuronal function showed altered expression patterns in a euglycemic state with insulin treatment. The Diabetes Control and Complications Trial (DCCT), a human clinical study, reported that vision can deteriorate with intensive insulin treatment in patients with long-standing poor glycemic control. $^{30}$
On the other hand, glucagon-like peptide-1 receptor agonist (GLP-1RA) has many beneficial effects in the treatment of T2D, including anti-inflammatory properties, glucose control, and $\beta$-cell protection, by both enhancing the secretion of insulin and down-regulating TXNIP expression. ${ }^{31-35}$ Additionally, through its anti-inflammatory properties, GLP-1RA has been shown to prevent microglial activation by toxins and is a good candidate for suppressing neuroinflammation and blocking the pathogenesis of Parkinson disease. ${ }^{36,37}$ In the field of ophthalmology, Hernandez et $\mathrm{al}^{38}$ found that GLP-1R is concentrated in the retina, and that GLP-1RA had neuroprotective effects in the retinas of both humans and $d b / d b$ mice, which are considered a typical animal model of T2D that exhibits hyperglycemia associated with obesity.

There have been several clinical reports analyzing the relationship between DR and macular thickness or retinal nerve fiber layer (NFL) thickness in T2D. ${ }^{30,39}$ However the timing of diabetes onset remains unclear, and these studies may not reflect very early changes in retinal layers. Furthermore, no study has explored the effect of GLP-1RAs on the inflammatory changes caused by TXNIP in the retina, or directly compared the early neuroprotective effects of GLP-1RAs on the retina with those of insulin.

Therefore, this study analyzed and compared the pathologic and associated morphologic changes caused by several inflammatory markers, including TXNIP on early diabetic retinas in an animal model of T2D. This investigation also compared the anti-inflammatory and/or neuroprotective effect in the retina and the optic nerve head of GLP-1RA treatment with insulin-treated, diabetic untreated $(d b / d b)$ and nondiabetic mice $(\mathrm{db} / \mathrm{dm})$.

\section{Materials and Methods}

\section{Animal Experiments}

Five-week-old male $d b / d b$ mice (type 2 diabetic) and $d b /$ $d m$ mice (nondiabetic) were obtained from Charles River Japan (Kanagawa, Japan). Animals received an i.p. glucose tolerance test (baseline), which has been described previously. ${ }^{40}$ The $d b / d b$ mice were then divided into three groups: the lixisenatide group (LIX) $(n=7$, GLP-1RA; Sanofi, Paris, France), the insulin group (INS) with a 
Table 2 Body Weights and Serum Glucose Levels by Group

\begin{tabular}{lllc}
\hline Parameter & $d b / d m$ & D-CON & INS \\
\hline Body weight, g $^{*}$ value* $^{*}$ & $27.3 \pm 1.6$ & $48.9 \pm 7.0$ & $54.2 \pm 1.5$ \\
Post hoc analysis $^{\dagger}$ & $<0.001$ & & \\
Serum glucose, mg/dL & D-CON, INS, LIX $>d b / d m$ & & \\
0 min & & & \\
30 min & $63.6 \pm 16.1$ & $366.9 \pm 44.9$ & $278.6 \pm 121.5$ \\
60 min & $89.2 \pm 39.6$ & $554.6 \pm 92.9$ & $554.3 \pm 66.8$ \\
90 min & $87.2 \pm 45.4$ & $747.1 \pm 138.0$ & $639.1 \pm 86.0$ \\
120 min & $79.2 \pm 38.2$ & $757.4 \pm 60.0$ & $693.7 \pm 135.2$ \\
$P$ value $(120$ minutes) & $71.2 \pm 30.8$ & $788.6 \pm 132.5$ & $698.7 \pm 72.8$ \\
Post hoc analysis & $<0.001$ & & $320.0 \pm 125.5$ \\
\hline
\end{tabular}

Data are expressed as means \pm SEM.

*Analysis of variance.

${ }^{\dagger}$ Tukey honestly significant difference (HSD).

$d b / d m$, nondiabetic mice; D-CON, untreated diabetic mice; INS, diabetic mice treated with insulin; LIX, diabetic mice treated with lixisenatide.

controlled glucose concentration based on the glucose concentration of lixisenatide $(n=7)$, and the diabetic control group (D-CON) (no treatment, $n=7$ ). LIX mice were treated with i.p. injections of lixisenatide $(500 \mu \mathrm{g} / \mathrm{kg} /$ day), and INS mice were treated with i.p. injections of Humulin R (human recombinant insulin, average $52 \mathrm{U} / \mathrm{kg} /$ day; Eli Lilly, Indianapolis, IN) for 8 weeks. Based on the previous studies,${ }^{41-43}$ the authors decided the i.p. dose of lixisenatide as $500 \mu \mathrm{g} / \mathrm{kg}$.

Nondiabetic mice were selected as the normal control group $(\mathrm{db} / \mathrm{dm} ; n=5)$. Mice were housed under controlled conditions of temperature $\left(20^{\circ} \mathrm{C}\right.$ to $\left.26^{\circ} \mathrm{C}\right)$ and humidity $(50 \pm 10 \%)$ with a 12-hour light-dark cycle. Mice received a gamma ray-sterilized diet (TD2018S; Harlan Laboratories, Indianapolis, IN).

Body weight, food and water consumption, and blood glucose concentrations were monitored daily. The dose of Humulin $\mathrm{R}$ was adjusted weekly based on the glucose concentration oflixisenatide. Blood glucose concentrations were measured by tail snipping (glucose assay kit ACCUCHEK Performa; Roche, Basel, Switzerland).

At the end of the 8-week treatment, mice were anesthetized by an i.p. injection of a mixture containing ketamine $(100 \mathrm{mg} / \mathrm{kg})$ and xylazine $(5 \mathrm{mg} / \mathrm{kg})$ and were sacrificed by cervical dislocation, after which the eyes were enucleated. Whole-eye samples were taken to evaluate mRNA and protein levels, and for histologic examinations.

\section{Ethics Statement}

This study was approved by the institutional animal care and use committee and department of laboratory animals of the Catholic University of Korea, Songeui Campus, which was accredited as an Excellent Animal Laboratory Production Facility by the Korea Food and Drug Administration in 2017 and acquired Association for Assessment and Accreditation of Laboratory Animal Care International full accreditation in 2018. All animal research procedures were conducted in accordance with the Laboratory Animals Welfare Act, NIH's Guide for the Care and Use of Laboratory Animals, ${ }^{44}$ and the Guidelines and Policies for Rodent Experiments provided by the institutional animal care and use committee of the School of Medicine of the Catholic University of Korea (approval number: CUMS-20170249-04).

\section{Tissue Processing}

After the eyes were enucleated, the neurosensory retina from one of the eyes was immediately separated. The other eye was dipped in formol acetic alcohol (mixture of $95 \%$ ethyl alcohol, 10\% neutral formalin, and glacial acetic acid, 17:2:1) for 1 minute and fixed in $0.1 \mathrm{~mol} / \mathrm{L}$ phosphate buffer (pH 7.4) containing 4\% paraformaldehyde for 2 hours at $4{ }^{\circ} \mathrm{C}$. The anterior segment of the eye was dissected away, the vitreous was cleared, and the eyecup (posterior segment) was left for fixation overnight. Eyecups were embedded in paraffin and sectioned. Serial sections $7-\mu \mathrm{m}$ thick near the optic nerve head were prepared for retinal immunofluorescence staining, including terminal deoxynucleotidyl transferase-mediated dUTP nick-end labeling (TUNEL) and morphology.

\section{RNA Extraction and qPCR}

Total RNA was extracted from neurosensory retinas using the RNeasy Mini Kit (Qiagen, Valencia, CA). The RNA was reverse transcribed using a cDNA synthesis kit (PrimeScript RT Reagent Kit; Takara Bio, Kusatsu, Japan) according to the manufacturer's instructions. Quantitative PCR (qPCR) was performed using TOPreal qPCR $2 \times$ PreMIX (Enzynomics, Daejeon, Korea) on a Roche Diagnostics LightCycler 2.0 Real-Time PCR System (Roche, Mannheim, Germany). Reactions for each sample were run in triplicate, cycle thresholds were normalized to GAPDH expression, and comparative 
A

GS

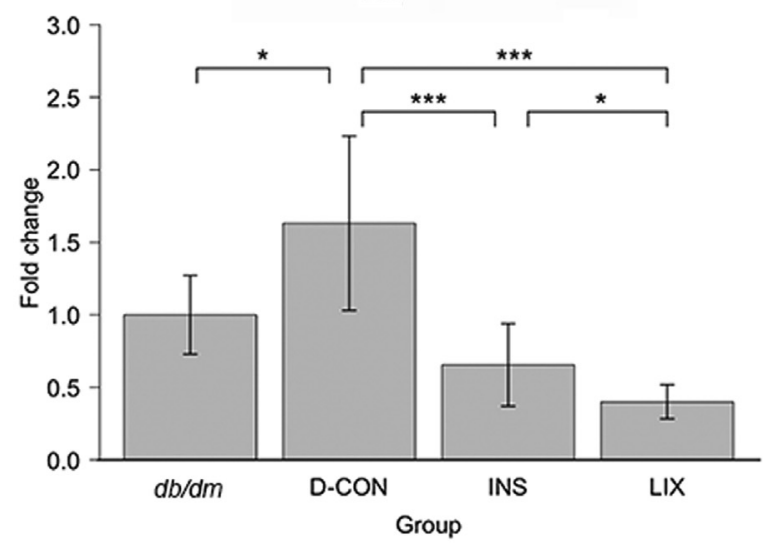

B

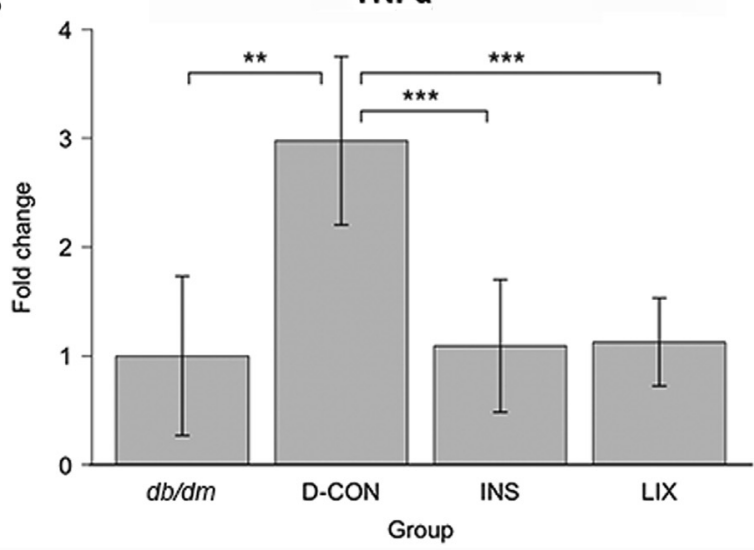

C

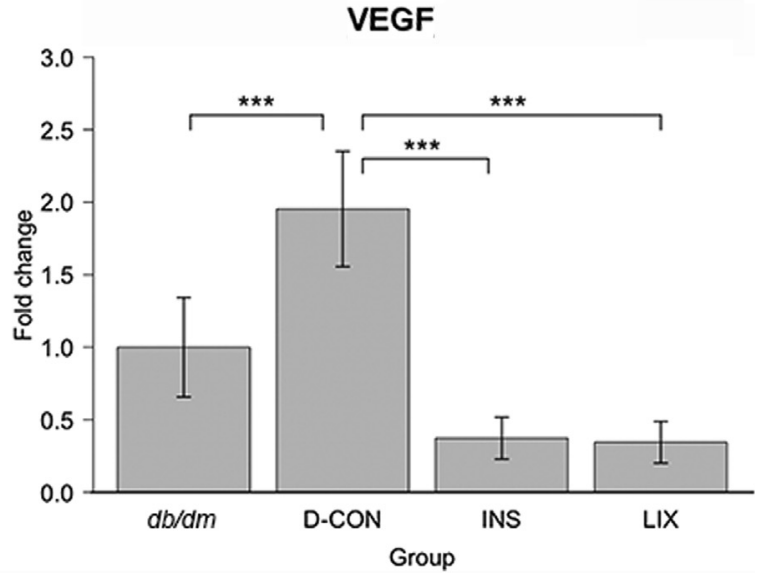

Figure 1 Relative mRNA expression levels. A: Glutamine synthetase (GS) $(P=0.007)$. B: Tumor necrosis factor alpha (TNF- $\alpha)$. C: Vascular endothelial growth factor (VEGF) based on the average expression levels of the nondiabetic mice group $(d b / d m)$ (set as 1.0). Data are expressed as means \pm SEM. $n=5 \mathrm{db} / \mathrm{dm} ; n=7 \mathrm{D}$-CON, INS, and LIX. ${ }^{*} P<0.05$, ${ }^{* *} P<0.01$, and ${ }^{* * *} P<0.001$. $d b / d m$, nondiabetic mice; D-CON, untreated diabetic mice; INS, diabetic mice treated with insulin; LIX, diabetic mice treated with lixisenatide.

quantitation was performed using LightCycler 167 software version 4.1 (Roche).

qPCR was performed using primers for glutamateammonia ligase $(G L U L)$, also known as glutamine synthetase (GS), and glial fibrillary acidic protein (GFAP), known glial cell activation markers ${ }^{45,46}$; tumor necrosis factor $(T N F)$, also known as tumor necrosis factor alpha $(\mathrm{TNF}-\alpha)$ which induces expression of other inflammatory markers ${ }^{47,48}$; TXNIP, which links oxidative stress to inflammation and apoptosis in $\mathrm{T} 2 \mathrm{D}^{12,13,49,50}$; and VEGF, an angiogenic factor induced in retinal ischemia and in inflammatory processes in T2D. ${ }^{12,18,23,51,52}$ Primer sequences are listed in Table 1.

\section{Western Blot Analysis}

The total protein from each neurosensory retina was extracted in $100 \mu \mathrm{L}$ of radioimmunoprecipitation assay buffer containing protease and phosphatase inhibitor (Sigma-Aldrich, St. Louis, MO) using a handheld homogenizer. Protein quantification was performed using the BCA protein assay kit (Pierce; Thermo Fisher Scientific, Waltham, MA). Then, $10 \mu \mathrm{g}$ of protein was loaded on $12 \%$ polyacrylamide gels and transferred to polyvinylidene difluoride membranes. Polyvinylidene difluoride membranes were blocked with $5 \%$ bovine serum albumin in Tween20/TBS at room temperature for 60 minutes and incubated at $4{ }^{\circ} \mathrm{C}$ overnight with primary antibodies (GFAP 1:500; Abcam, Cambridge, UK; TXNIP 1:250; Abcam; and $\beta$-actin 1:500; Cell Signaling Technology, Beverly, MA). The blots were then incubated with species-specific horseradish peroxidase-conjugated secondary antibody for 60 minutes at room temperature. Immunoreactive bands were visualized using an ECL Advance Western Blotting Detection Reagent (GE Healthcare, Little Chalfont, UK) and determined using a luminescent image analyzer (LAS-4000 mini; Fujifilm, Tokyo, Japan). Densitometric data for the immunoreactive bands were analyzed using ImageJ software version $1.52(\mathrm{NIH}$, Bethesda, MD; http://imagej.nih. gov/ij). Data were normalized to the specified loading controls.

\section{Colorimetric Analysis for Apoptosis Assessment}

Apoptosis was evaluated using the Dead End Colorimetric TUNEL system (Promega Corporation, Madison, WI). Briefly, sections were deparaffinized, equilibrated in phosphate-buffered saline (PBS), permeabilized with proteinase $\mathrm{K}$, post-fixed in $4 \%$ paraformaldehyde, and incubated in terminal deoxynucleotidyl transferase reaction mix for 1 hour at $37^{\circ} \mathrm{C}$ in the dark. The reactions were terminated by immersing the slides in $2 \times$ saline-sodium citrate for 15 minutes at room temperature. After washing the slides three times in PBS for 5 minutes at room temperature, the slides were immersed in $0.3 \% \mathrm{H}_{2} \mathrm{O}_{2}$ in PBS for 3 to 5 minutes at room temperature, and then washed three times in PBS. Subsequently, horseradish peroxidase-labeled streptavidin in the Dead End colorimetric TUNEL system was added to each slide, and the slides were incubated for 30 minutes at room temperature. Slides were washed three 


\section{qPCR results}

A

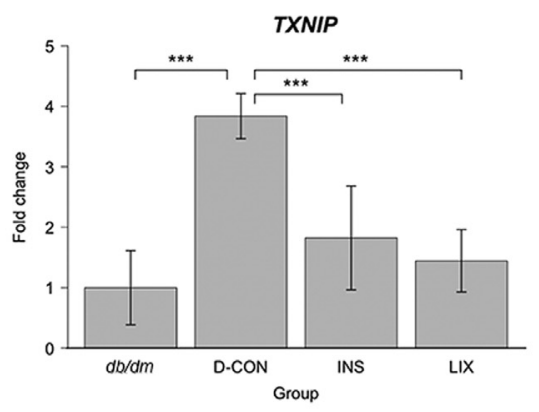

B

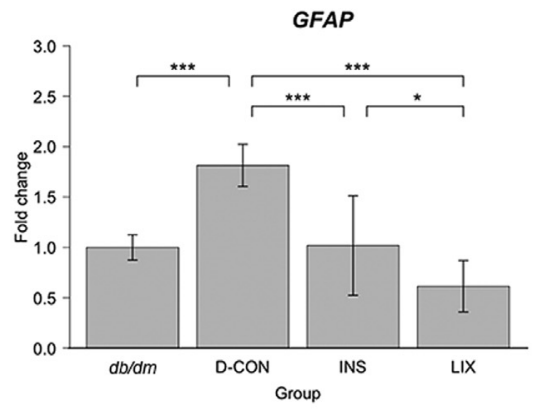

C

Western blot results
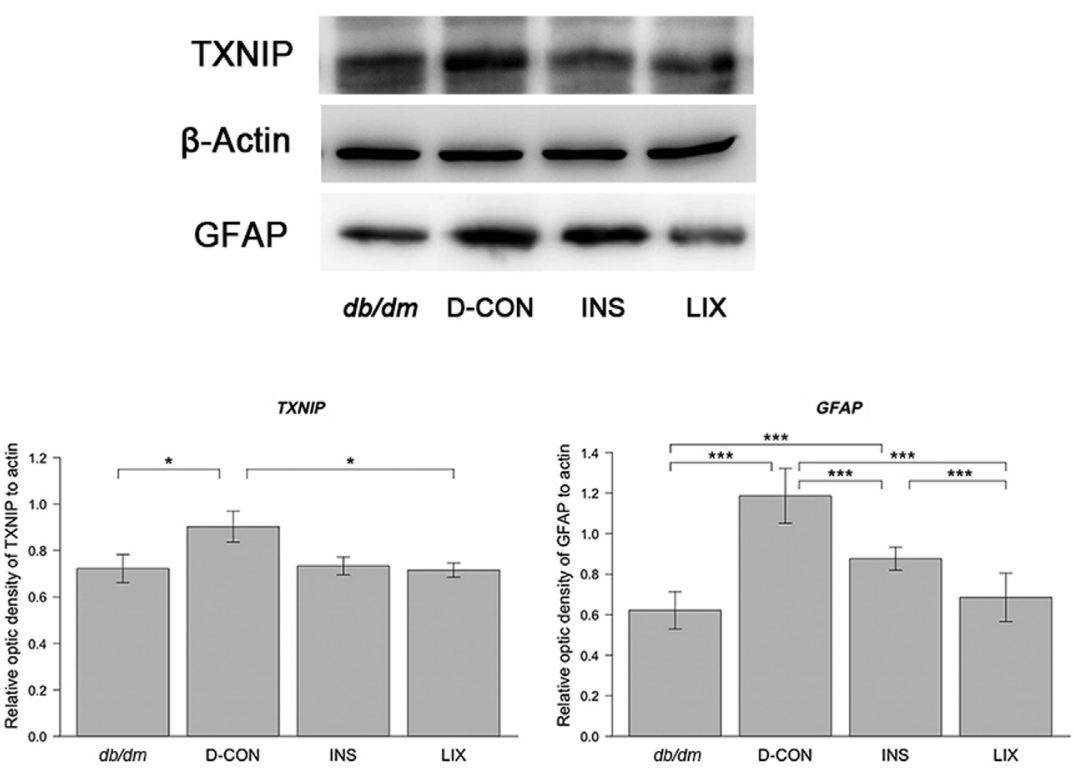

Figure 2 A and B: Relative mRNA expression levels of thioredoxin-interacting protein (TXNIP) (A), and glial fibrillary acidic protein (GFAP) (B) based on the average expression levels of the nondiabetic mice group $(d b / d m)$ (set as 1.0 ); $P=0.047$. C: TXNIP and GFAP assessment by Western blotting (top panel), statistical analysis of relative optic density of TXNIP (bottom left panel), and GFAP (bottom right panel) to $\beta$-actin among the groups based on the Western blot immunoreactive bands in the neurosensory retina. Data are expressed as means \pm SEM. $n=5 \mathrm{db} / \mathrm{dm}$; $n=7$ D-CON, INS, and LIX. ${ }^{*} P<0.05$, $* * * P<0.001 . d b / d m$, nondiabetic mice; D-CON, untreated diabetic mice; INS, diabetic mice treated with insulin; LIX, diabetic mice treated with lixisenatide; $\mathrm{PPCR}$, quantitative PCR. times in PBS, and chromogen solution was added to each slide and developed until a light brown background was observed. Slides were washed four times in deionized water, and the stained cells were mounted onto microscope slides in Faramount aqueous mounting medium (Dako, Santa Clara, CA). Five microscopic images per group were captured using the Olympus cellSens Dimension software version 1.14 (IX83; Olympus Corporation, Tokyo, Japan).

\section{Immunohistochemical Analysis for Glial Activation and Neuroinflammation}

Glial activation was evaluated by fluorescence microscopy using specific antibodies against GFAP. Oxidative stress was evaluated using the same method with specific antibodies against TXNIP. Paraffin-embedded sections $(3 \mu \mathrm{m})$ were subjected to immunohistochemical examination. After deparaffinization, sections were placed in citrate-buffered solution (pH 6.0) and heated for antigen retrieval. Endogenous peroxidase activity was blocked with $3 \%$ hydrogen peroxide treatment, and nonspecific binding was blocked with normal nonimmune serum. Sections were then incubated with mouse anti-GFAP (1:50 dilution prepared in blocking solution; Abcam) and rabbit anti-TXNIP (1:100 dilution prepared in blocking solution; Abcam) overnight at $4^{\circ} \mathrm{C}$ in a humid atmosphere. After three washes in PBS for 5 minutes each, the sections were incubated with Alexa Fluor 488 goat anti-mouse and Alexa Fluor 549 goat anti-rabbit secondary antibodies (1:100 dilution prepared in blocking solution; Life Technologies, Madrid, Spain). The sections were washed three times in PBS, mounted with VectaStain mounting medium (VECTASHIELD with DAPI; Vector Laboratories, Burlingame, CA), and images were captured using inverted fluorescence microscopy (IX83; Olympus Corporation) using the Olympus cellSens Dimension program (Olympus Corporation). All captured neurosensory 

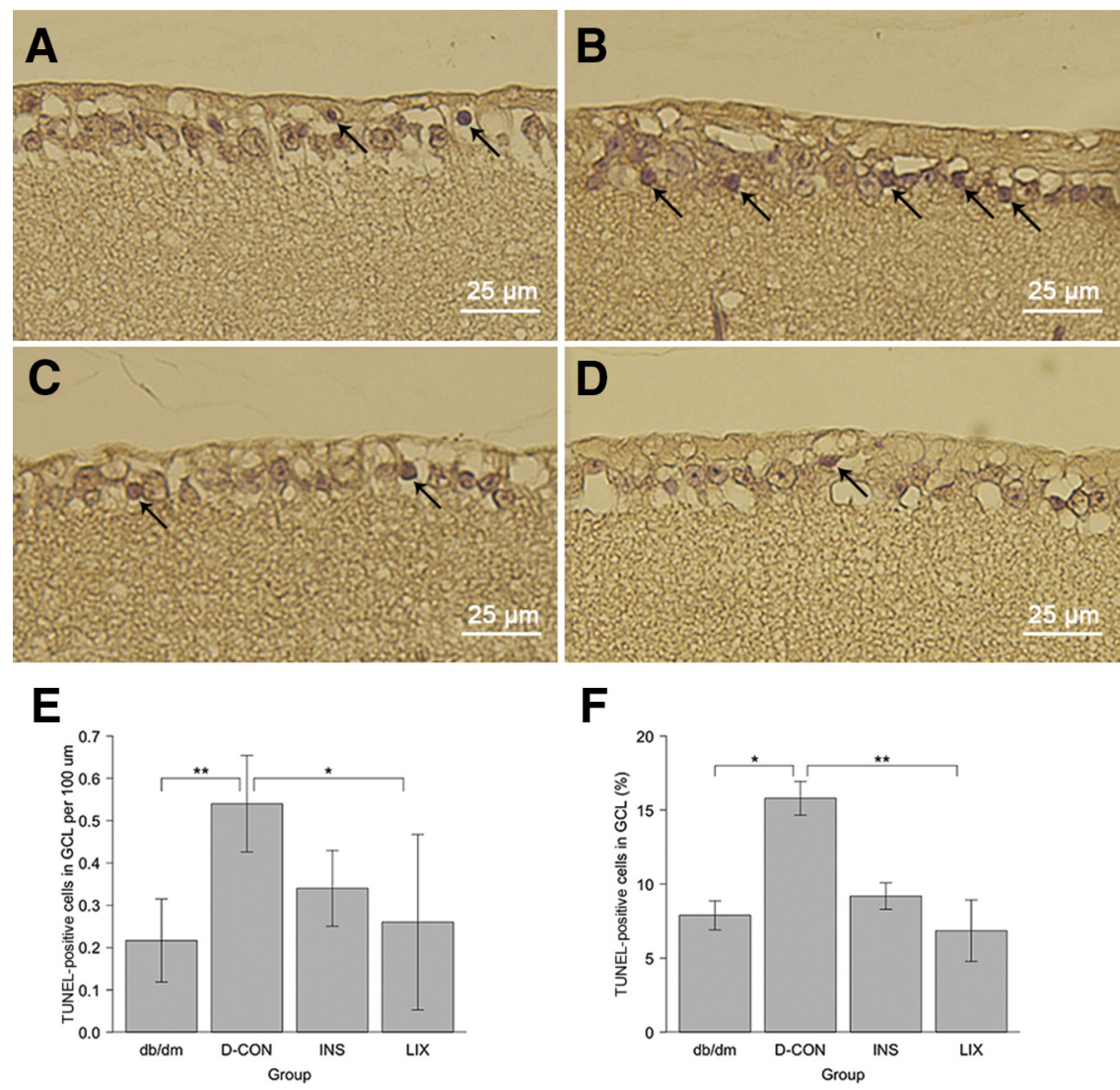

Figure 3 Terminal deoxynucleotidyl transferase dUTP nick-end labeling (TUNEL)-positive cells in the ganglion cell layer (GCL). A: $d b / d m$. B: D-CON. C: INS. D: LIX. Arrows indicate TUNELpositive cells. E: The counts of TUNEL-positive cells. F: The ratio of TUNEL-positive cells to normal cells in the GCL. Data are expressed as means \pm SEM. $n=5 d b / d m ; n=7$ D-CON, INS, and LIX. ${ }^{*} P<0.05,{ }^{*} * P<0.01$. Scale bars: $25 \mu \mathrm{m}$ (A-D). $d b / d m$, nondiabetic mice; D-CON, untreated diabetic mice; INS, diabetic mice treated with insulin; LIX, diabetic mice treated with lixisenatide. retinal images were exported from the system into ImageJ software for analysis. To quantify immunofluorescence, each image was converted from 8-bit to three channels (red, green, and blue). Red channel values represented TXNIP staining (red fluorescence), and green values represented GFAP staining (green fluorescence). Sets of obtained values of TXNIP and GFAP were compared among the groups. Densitometric image analysis using ImageJ has been described previously, ${ }^{53}$ and this method was applied for our analytical purposes. Results are presented as densitometry arbitrary units.

\section{Retinal Morphometry}

After deparaffinization and rehydration, sections were stained with hematoxylin and eosin and images of these sections were acquired with a microscope (IX83; Olympus Corporation) using the Olympus cellSens Dimension program (Olympus Corporation). First, the central neurosensory retina was obtained and defined as the region within $300 \mu \mathrm{m}$ of the optic nerve head margin when the plane passed through the optic nerve. The peripheral neurosensory retina was then defined as a section acquired anywhere outside the $300-\mu \mathrm{m}$ section that had been described previously. ${ }^{54}$ Measurements were taken at three different regions from both the central and peripheral neurosensory retina, and the average was defined as the thickness of the corresponding layer. Layer measurements of sections were performed using the Olympus cellSens Dimension program (Olympus Corporation) to quantify the total neurosensory retinal, outer nuclear layer, INL, and NFL thicknesses.

\section{Data Analysis}

Quantitative variables were expressed as means \pm SEM. Measured data were compared using analysis of variance. Statistical analyses were computerized using $\mathrm{R}$ software version 3.5.2 ( $\mathrm{R}$ Foundation for Statistical Computing, Vienna, Austria). Statistical significance was set at $P<0.05$.

\section{Results}

\section{Body Weight and Blood Glucose Levels}

The mean body weights and blood glucose concentrations of the experimental mice are shown in Table 2. At 8 weeks, the body weights of D-CON, INS, and LIX were higher than that of $\mathrm{db} / \mathrm{dm}$, and blood glucose concentrations at 120 minutes were significantly lower in $\mathrm{db} / \mathrm{dm}$ than in the other groups. The blood glucose concentration of D-CON was 


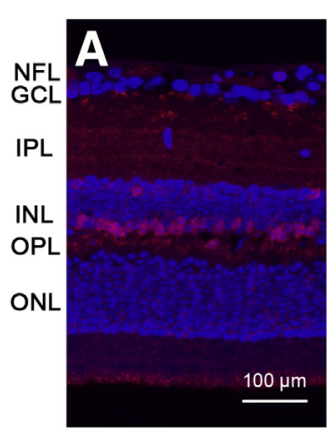

$d b / d m$

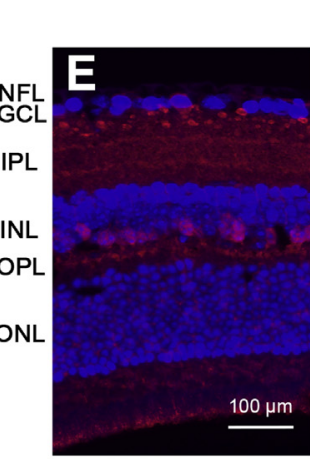

$d b / d m$

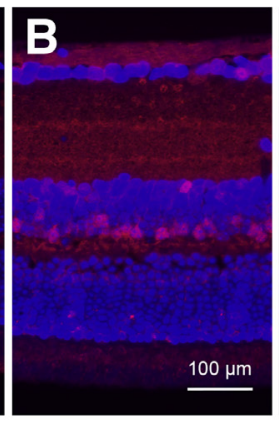

D-CON

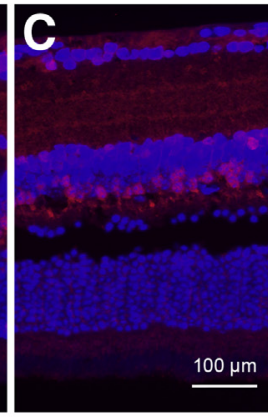

INS

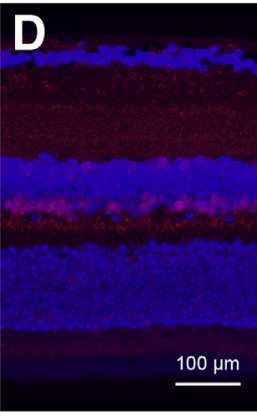

LIX

Peripheral retina

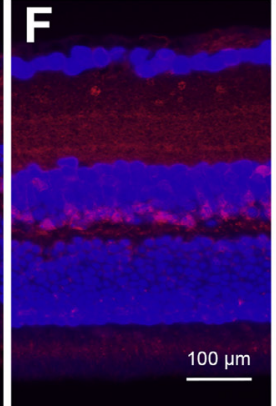

D-CON

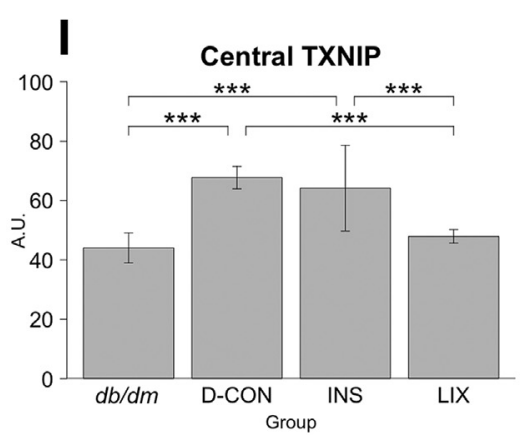

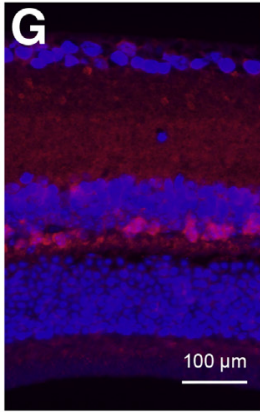

INS

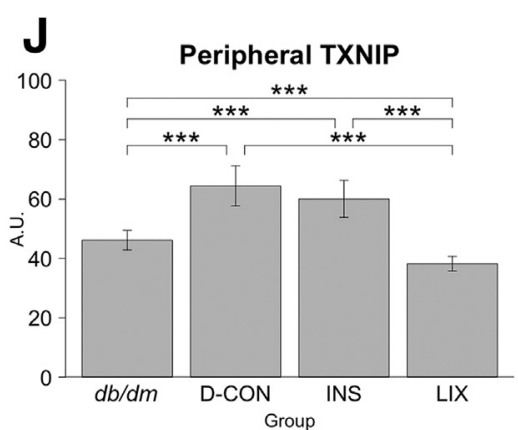

Figure 4 Comparisons of thioredoxininteracting protein (TXNIP) immunofluorescence (red) among the groups. A-D: Central neurosensory retina. E-H: Peripheral neurosensory retina. I: Statistical analysis of TXNIP fluorescence intensity (A.U.) among the groups in the central neurosensory retina. J: Statistical analysis of TXNIP fluorescence intensity (A.U.) among the groups in the peripheral neurosensory retina. Data are expressed as means \pm SEM. $n=5 d b / d m$; $n=7$ D-CON, INS, and LIX. ${ }^{* * *} P<0.001$. Scale bars: $100 \mu \mathrm{m}(\mathbf{A}-\mathbf{H})$. A.U., arbitrary units; $d b / d m$, nondiabetic mice; D-CON, untreated diabetic mice; GCL, ganglion cell layer; GLP-1RA, glucagon-like protein-1 receptor agonist; INL, internal nuclear layer; INS, diabetic mice treated with insulin; IPL, internal plexiform layer; LIX, diabetic mice treated with lixisenatide; NFL, nerve fiber layer; $\mathrm{ONL}$, outer nuclear layer; $\mathrm{OPL}$, outer plexiform layer. higher than those of INS and LIX. As mentioned in Materials and Methods, the blood glucose concentrations of INS and LIX did not differ significantly.

\section{Quantitative RT-PCR}

The mRNA levels of GS, TNF- $\alpha$, VEGF (Figure 1), TXNIP and GFAP (Figure 2, A and B) were significantly higher in D-CON than in the $d b / d m$ mice (all $P<0.05$ ). Both INS and LIX exhibited significantly lower mRNA levels of GS, TNF- $\alpha$, VEGF (Figure 1), TXNIP, and GFAP (Figure 2, A and B) than D-CON (all $P<0.001$ ). Compared with INS, LIX showed significantly lower levels of GS (Figure 1) $(P=0.007)$ and GFAP (Figure $2 \mathrm{~B})(P=0.047)$, suggesting that lixisenatide treatment reduced the expression of glial activation markers in early type 2 DR.
Western Blot

D-CON significantly increased TXNIP expression compared with $d b / d m$ and LIX (all $P<0.05$ ). The TXNIP concentration did not differ significantly between INS and D-CON (Figure 2C).

D-CON showed significantly increased GFAP expression compared with the other groups (all $P<0.001$ ). LIX significantly decreased GFAP expression compared with INS $(P<0.001)$ (Figure $2 \mathrm{C})$.

\section{Apoptosis}

The count and incidence of TUNEL positive cells to nonapoptotic cells in the ganglion cell layer was analyzed (Figure 3 ). D-CON showed a significantly higher apoptotic cell count $(P<0.004)$ and incidence $(P<0.019)$ than $d b /$ 


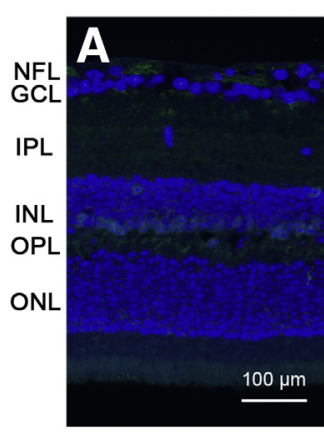

$d b / d m$

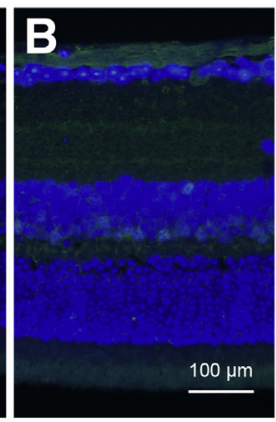

D-CON

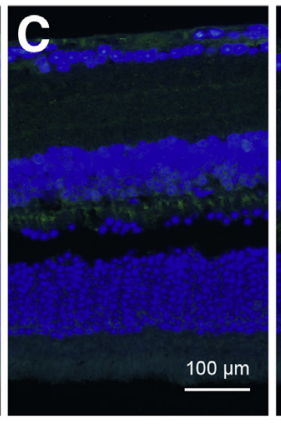

INS

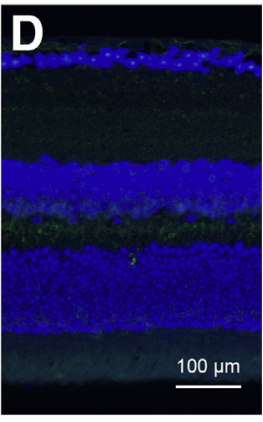

LIX
Peripheral retina

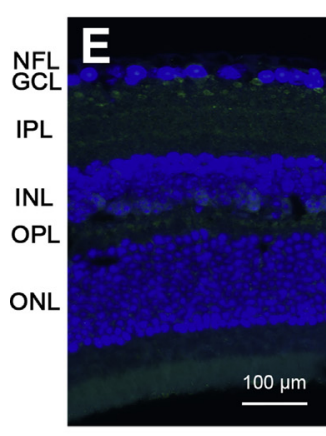

$d b / d m$

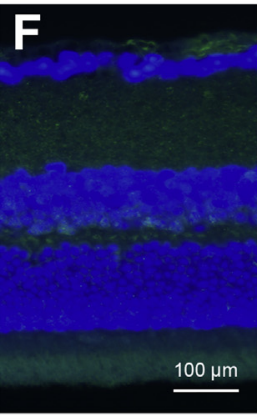

D-CON

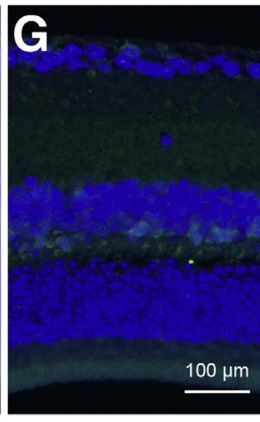

INS

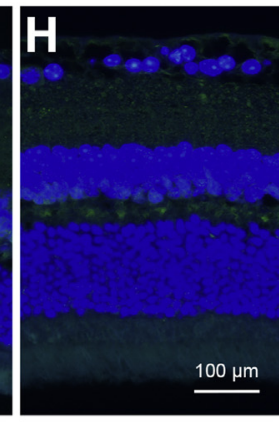

LIX

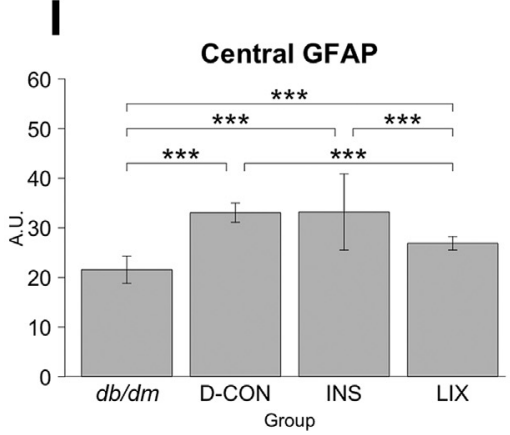

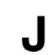

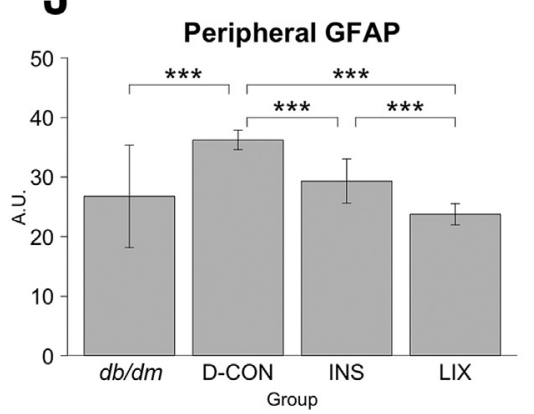

Figure 5 Comparisons of glial fibrillary acidic protein (GFAP) immunofluorescence (green) among the groups. A-D: Central neurosensory retina. E-H: Peripheral neurosensory retina. I: Statistical analysis of GFAP fluorescence intensity (A.U.) among the groups in the central neurosensory retina. J: Statistical analysis of GFAP fluorescence intensity (A.U.) among the groups in the peripheral neurosensory retina. Data are expressed as means \pm SEM. $n=5 \mathrm{db} / \mathrm{dm} ; n=7$ D-CON, INS, and LIX. ${ }^{* * *} P<0.001$. Scale bars: $100 \mu \mathrm{m}(\mathbf{A}-\mathbf{H})$. A.U., arbitrary units; $d b / d m$, nondiabetic mice; D-CON, untreated diabetic mice; $\mathrm{GCL}$, ganglion cell layer; GLP-1RA, glucagon-like protein-1 receptor agonist; INL, internal nuclear layer; INS, diabetic mice treated with insulin; IPL, internal plexiform layer; LIX, diabetic mice treated with lixisenatide; NFL, nerve fiber layer; $0 N L$, outer nuclear layer; $\mathrm{OPL}$, outer plexiform layer. $d m$. LIX showed significantly decreased apoptotic cell count $(P<0.02)$ and incidence $(P<0.009)$ compared with $\mathrm{D}-$ $\mathrm{CON}$, whereas INS did not. However, the apoptotic cell count and incidence were not significantly different in both LIX and INS.

In agreement with the TUNEL results, D-CON showed significantly greater TXNIP and GFAP immunofluorescence staining than did $d b / d m$ in both the central and peripheral neurosensory retina (Figures 4, and 5, I and J). LIX showed significantly less TXNIP and GFAP immunohistochemical staining compared with D-CON in both the central and peripheral neurosensory retina, but INS showed significantly lower GFAP immunohistochemical staining compared with D-CON in the peripheral neurosensory retina only (Figures 4, and 5, I and J). LIX was associated with significantly reduced TXNIP and GFAP immunohistochemical staining than INS in both the central and peripheral neurosensory retina (Figures 4, and 5, I and $\mathbf{J}$ ).

In the optic nerve head, all groups showed similar TXNIP immunohistochemical staining (Figure 6). However, D-CON showed increased GFAP immunofluorescence staining compared with the other groups (Figure 7).

\section{Retinal Morphometry}

In the central neurosensory retina, there were no significant differences in total neurosensory retinal, outer nuclear layer, or INL thickness among all groups (Figures 8, A-D, and 9, $\mathrm{A}-\mathrm{C})$. The central NFL in D-CON was significantly thicker than that of $d b / d m(P=0.007)$. The central NFL of LIX was significantly thinner than that of D-CON $(P=0.001)$, 
TXNIP

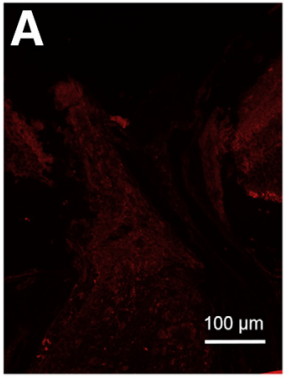

$d b / d m$

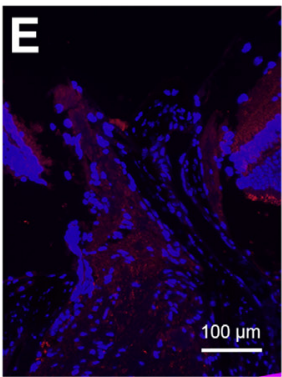

$d b / d m$

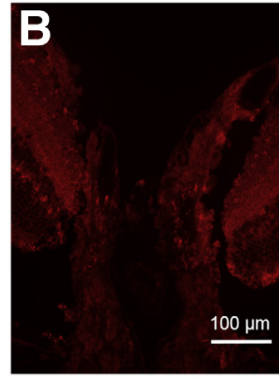

D-CON

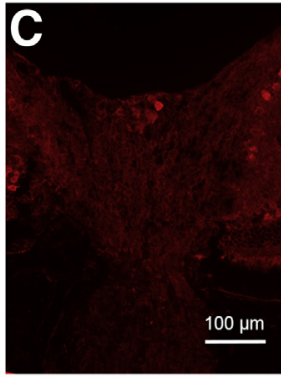

INS

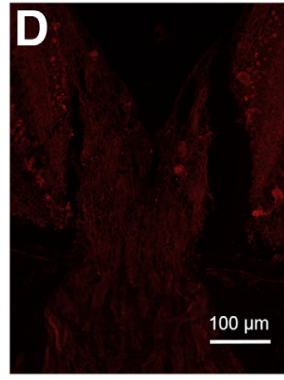

LIX
TXNIP + DAPI

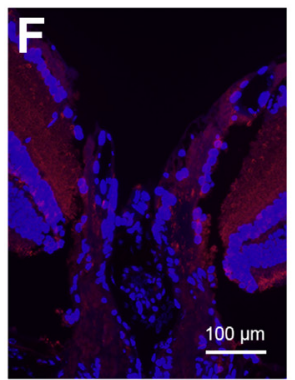

D-CON

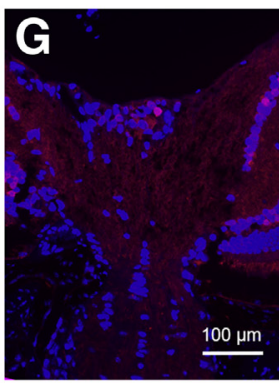

INS

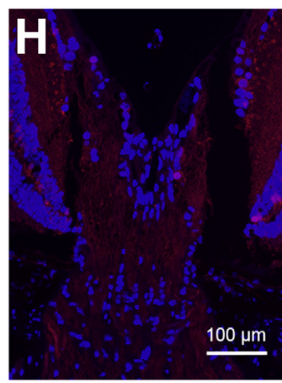

LIX

Figure 6 Immunohistochemistry of thioredoxin-interacting protein (TXNIP) in the optic nerve head (ONH). A-D: All groups showed similar immunohistochemical staining. E-H: Merged immunohistochemical images among the groups. $n=5 \mathrm{db} / \mathrm{dm} ; n=7 \mathrm{D}-\mathrm{CON}$, INS, and LIX. Scale bars: $100 \mu \mathrm{m}$ (A-H). $d b / d m$, nondiabetic mice; D-CON, untreated diabetic mice; INS, diabetic mice treated with insulin; LIX, diabetic mice treated with lixisenatide.

but there was no significant difference in thickness between INS and D-CON (Figure 9D).

In the peripheral neurosensory retina, total neurosensory retinal thickness was significantly greater in D-CON than in $d b / d m$ (Figures 8, E-H, and 10) $(P=0.041)$. There were no significant differences in thickness among D-CON, INS, and LIX.

The thickness of peripheral INL was significantly greater in D-CON than in $d b / d m$ (Figure 10$)(P=0.049)$. There was no difference in thickness between INS and D-CON, but the peripheral INL was significantly thicker in INS than in $d b / d m$ (Figure 10) $(P=0.018)$. The peripheral INL of LIX was significantly thinner than that of INS $(P=0.021)$, but did not differ significantly from that of $d b / d m$ (Figure 10).

The peripheral NFL in D-CON was significantly thicker than that of $d b / d m(P<0.001)$, and those in INS and LIX were also significantly thinner than that of D-CON (all $P<0.001$ ) (Figure 10). INS only showed significant differences in peripheral NFL thickness compared with DCON, whereas LIX showed significant differences in the central and peripheral NFL (Figures 9D and 10D).

\section{Discussion}

This study showed that oxidative stress and inflammation increased in an animal model of early type 2 diabetic retina based on GS, TNF- $\alpha$, VEGF, GFAP, and TXNIP mRNA levels, whereas insulin or lixisenatide treatment reversed these changes (Figures 1 and 2, A and B). However, there were no significant differences in TNF- $\alpha$, VEGF, or TXNIP mRNA levels between INS and LIX at 8 weeks after treatment (Figures 1 and 2A). According to the Western blot analysis, D-CON showed significantly increased TXNIP and GFAP expression levels compared to $d b / d m$ in the neurosensory retina (Figure 2C). LIX showed significantly decreased TXNIP and GFAP expression compared with D-CON, whereas INS showed only decreased GFAP expression in the neurosensory retina (Figure 2C).

In detail, TXNIP protein levels were significantly higher in the central and peripheral neurosensory retina in INS compared with $\mathrm{db} / \mathrm{dm}$ and LIX in the early type 2 diabetic retina (Figure 4), suggesting that lixisenatide suppressed TXNIP in the early type 2 diabetic retina to a level similar to 


\section{GFAP}

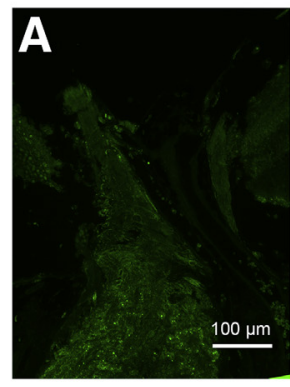

$d b / d m$

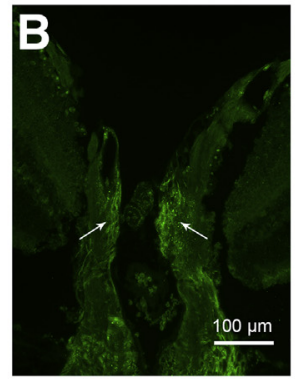

D-CON

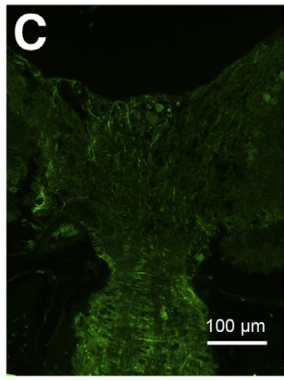

INS

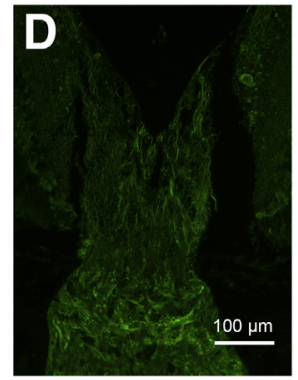

LIX

\section{GFAP + DAPI}

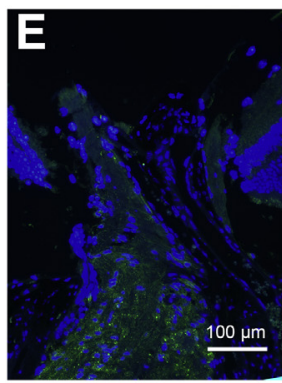

$d b / d m$

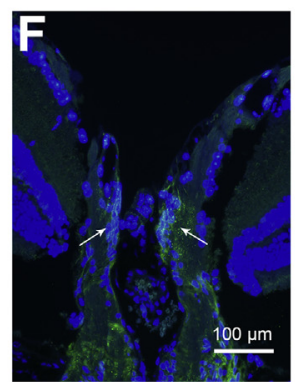

D-CON

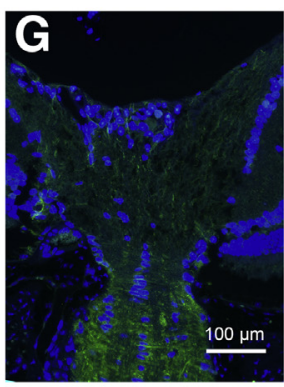

INS

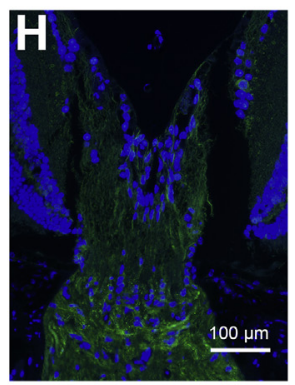

LIX

Figure 7 Immunohistochemistry of glial fibrillary acidic protein (GFAP) in the optic nerve head (ONH). A-D: D-CON showed increased immunohistochemical staining. E-H: Merged immunohistochemical images among the groups. Arrows (B and F) indicate locations showing increased GFAP staining of DCON. $n=5 d b / d m ; n=7$ D-CON, INS, and LIX. Scale bars: $100 \mu \mathrm{m}(\mathbf{A}-\mathbf{H}) . d b / d m$, nondiabetic mice; D-CON, untreated diabetic mice; INS, diabetic mice treated with insulin; LIX, diabetic mice treated with lixisenatide.

that in normal control mice, whereas insulin did not. To control for the effect of hyperglycemia, insulin doses were adjusted in the INS mice based on the glucose concentrations in the LIX mice; thus, these anti-inflammatory results of TXNIP suppression were dependent on the effects of GLP-1RA after accounting for hyperglycemia. Additionally, insulin had little or no suppressive effect on TXNIP in the early type 2 diabetic retina in this study.

\section{Central neurosensory retina}

\section{Peripheral neurosensory retina}

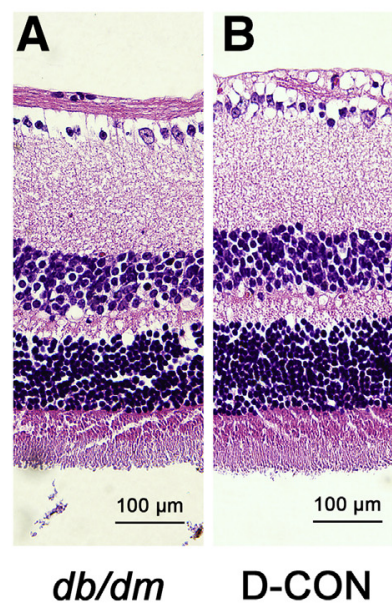

C

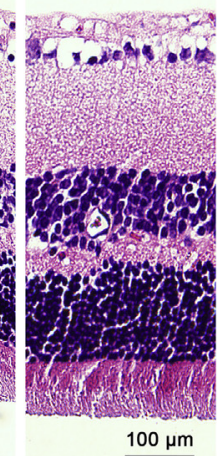

INS
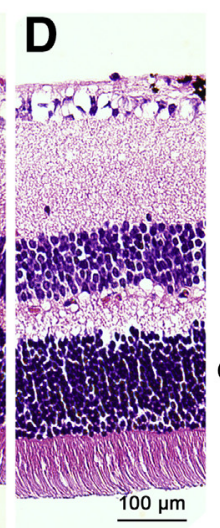

LIX

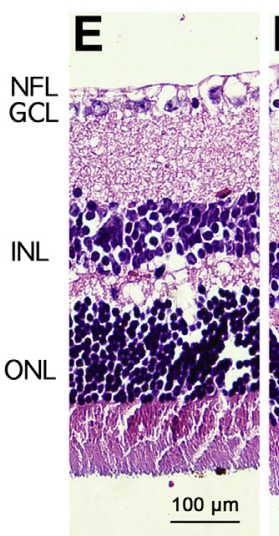

$d b / d m$
$\mathbf{F}$

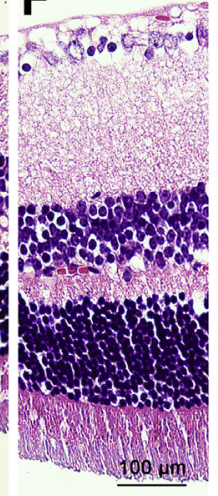

D-CON

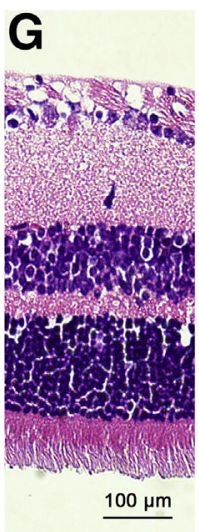

INS
H

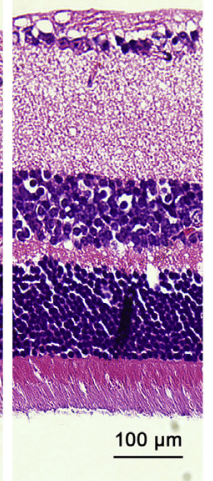

LIX

Figure 8 Sections of neurosensory retinal images stained with hematoxylin and eosin. A-D: Central neurosensory retina. E-H: Peripheral neurosensory retina. Scale bars: $100 \mu \mathrm{m}(\mathbf{A}-\mathbf{H})$. 

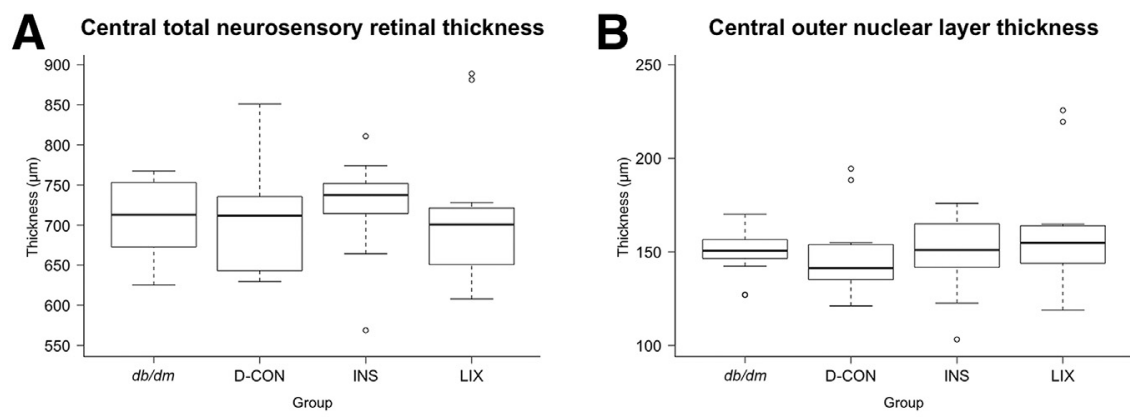

Figure 9 Comparison of central neurosensory retinal thickness among the groups. A: Central total neurosensory retina. B: Central outer nuclear layer. C: Central inner nuclear layer. D: Central nerve fiber layer. In the central nerve fiber layer, D-CON shows significantly greater thickness than $d b / d m$. LIX shows significantly reduced thickness compared with D-CON, whereas INS did not. Data are expressed as means \pm SEM. $n=5 d b / d m$; $n=7$ D-CON, INS, and LIX. ${ }^{*} P<0.01 . d b / d m$, nondiabetic mice; D-CON, untreated diabetic mice; INS, diabetic mice treated with insulin; LIX, diabetic mice treated with lixisenatide.

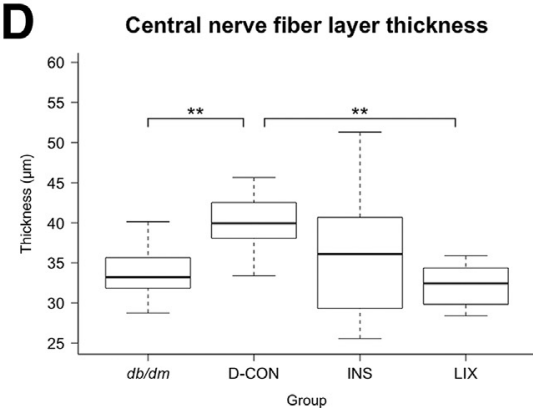

The mechanism of the effects of insulin and GLP-1RA on TXNIP remains unclear, but shares the common PI3K/Akt signaling pathway in pancreatic $\beta$-cells. ${ }^{14,34,55}$ Both insulin and GLP-1RA reduce caspase-3 activation, which is induced by TXNIP up-regulation and leads to cell death in the ganglion cell layer, ${ }^{13}$ via the PI3K/AKT signaling pathway by directly phosphorylating caspase- 9 in diabetic rat retinas. ${ }^{56,57}$ Insulin also suppresses TXNIP transcription by activating histone deacetylases via the PI3K/AKT signaling pathway. ${ }^{55}$ On the other hand, exendin-4, a GLP-1RA, also uses the PI3K/AKT signaling pathway and mediates proteasome-induced degradation of TXNIP via the cyclic AMP signaling pathway. ${ }^{34}$ Based on the study results and known mechanisms described above, the primary reason for the significant difference in TXNIP protein levels between INS and LIX is TXNIP proteasomal degradation in the early type 2 diabetic retina. However, further studies are required to support this hypothesis.

In the current study, lixisenatide reduced neuroinflammation in early type 2 diabetic retina more efficiently than insulin. LIX had lower mRNA levels of GS and GFAP, which are Müller cell- and glial cell-specific activation markers, than D-CON and INS (Figures 1 and 2B). A previous study reported different results regarding the mRNA expression of GS under diabetic versus nondiabetic conditions. Zhou et $\mathrm{al}^{58}$ reported that TXNIP suppressed the mRNA expression of GS by inducing oxidative stress in retinal Müller cells. However, their study was based on in vitro Müller cell cultures, in contrast to the current in vivo study. Lieth et $\mathrm{al}^{59}$ reported similar results to Zhou et $\mathrm{al}^{58}$ using experimental rat models, but even they observed an increase in $G S$ activity at 1 month after diabetes exhibition, although it was not statistically significant. It may be that early type 2 DR differs in terms of gene expression profile compared with typical type $2 \mathrm{DR}$, although further study is needed to confirm this.

TUNEL staining demonstrated that LIX had significantly lower apoptotic cell count and incidence than D-CON, whereas LIX did not show significant differences compared with $d b / d m$ (Figure 3). At the protein level, LIX showed decreased immunohistochemical staining for both TXNIP and GFAP in the central and peripheral neurosensory retinas compared with levels in D-CON and INS (Figures 4 and 5). Similarly, the INL in the peripheral neurosensory retina and the NFL in the central and peripheral neurosensory retina in LIX were significantly thinner than those in D-CON and INS (Figures 8, 9, and 10). In addition, GFAP immunohistochemical staining in the optic nerve head was lower in LIX than in D-CON (Figure 7). These results indicate that neuroinflammation in the early type 2 diabetic retina was significantly decreased with lixisenatide treatment compared with insulin treatment when controlling for hyperglycemia. These results support previous reports on neuroprotection via GLP-1RA treatment in type 2 DR. ${ }^{38,60,61}$

The neuroprotective mechanisms of GLP-1RA remain unclear, but may involve regulation of transcription factor $N F-k B$, an important downstream target of the aforementioned $P I 3 K / A K T$ signaling pathway that regulates inflammatory gene expression and mediates the proinflammatory response of microglial cells in Parkinson disease. ${ }^{62,63}$ GLP1RA improved insulin sensitivity in an obese mouse model by directly inhibiting inflammatory pathways in adipocytes, enhancing glucose uptake, and decreasing hyperglycemiainduced inflammation. ${ }^{64-66}$ In the retina, some reports 


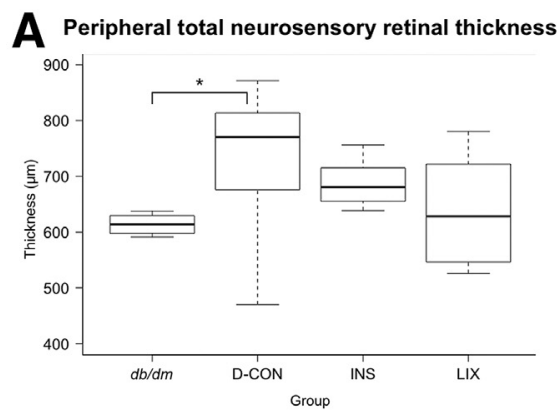

C Peripheral inner nuclear layer thickness

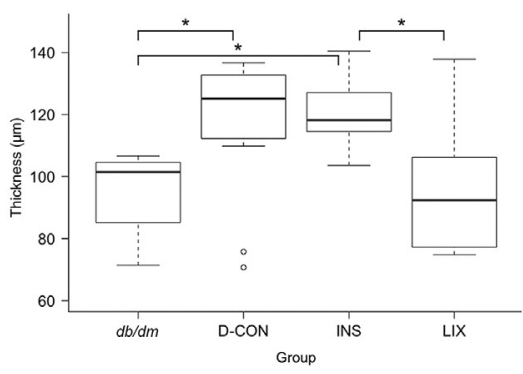

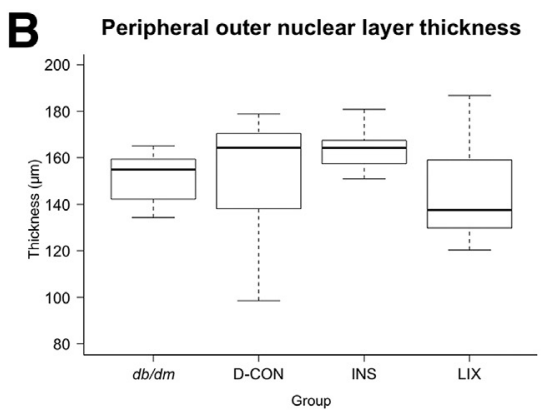

D

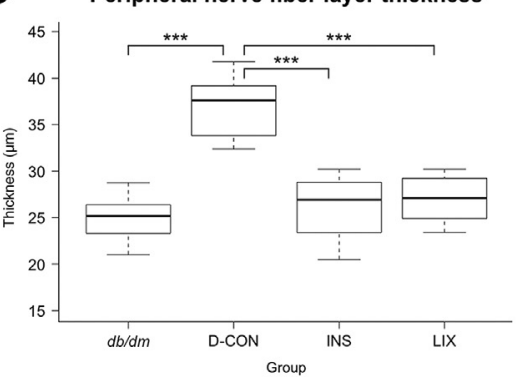

Figure 10 Comparison of peripheral neurosensory retinal thickness among the groups. In the peripheral retina, D-CON showed significantly greater thickness in the total neurosensory retinal, inner nuclear layer, and compared with $d b / d m$. A: Peripheral total neurosensory retina. B: Peripheral outer nuclear layer. C: In the peripheral inner nuclear layer, LIX shows significantly reduced thickness compared with D-CON, whereas INS does not. D: In the peripheral nerve fiber layer, LIX and INS show significantly decreased thickness compared with D-CON. Data are expressed as means \pm SEM. $n=5 d b / d m ; n=7$ D-CON, INS, and LIX. ${ }^{*} P<0.05,{ }^{* *} P<0.001 . d b / d m$, nondiabetic mice; D-CON, untreated diabetic mice; INS, diabetic mice treated with insulin; LIX, diabetic mice treated with lixisenatide. have shown that the $P I 3 K / A K T$ signaling pathway is important for the survival of retinal neurons. ${ }^{56,67}$ In addition, Vuong et $\mathrm{al}^{68}$ showed that the GLP-1RA liraglutide prevented retinal $p 53$ activation in T2D.

In this study, only lixisenatide induced a significant reduction in peripheral INL thickness compared to insulin treatment in early type 2 diabetic mice (Figure 10). This is noteworthy because physiological dysfunction of the INL in T2D patients was supported by electroretinogram, even without DR. ${ }^{69-71}$ The oscillatory potentials in the electroretinogram reflect inner retinal activity, ${ }^{72-74}$ particularly indicating ischemia in the DR, ${ }^{75-77}$ and predict the development of proliferative PDR. ${ }^{78,79}$ The somata of Müller cells in the retina are located in the middle of the $\mathrm{INL}^{80}$ and are negatively affected by inner retina dysfunction in DR. In an experiment in type 2 diabetic mice, Hernandez et $\mathrm{al}^{38}$ reported that GLP-1RA prevented the decreased a-wave, b-wave, and oscillatory potentials, as well as the increase in implicit time compared with type 2 diabetic mice. In addition, recent studies reported that peripheral lesions were predictive of an increased risk of DR progression. ${ }^{81,82}$ Silva et $\mathrm{al}^{82}$ argued that an increasing number of peripheral lesions substantially increased the risk of progression of DR and proliferative DR, independent of baseline DR severity and glycated hemoglobin levels. Therefore, the results from the current study suggest that GLP-1RAs are beneficial for the prognosis of the early type 2 DR by decreasing neuroinflammation in the peripheral INL.

The main difference between the current study and previous studies is that most other studies reported a decrease in the thickness of retinal layers in type $2 \mathrm{DR}^{30,39,83-87}$ However, the onset of T2D in patients was not clear in these studies, suggesting that their clinical course did not clearly reflect the early type 2 diabetic retina. The initial evaluation of patients may occur more than eight weeks after the onset of T2D. In contrast, this study initiated treatment as soon as T2D was confirmed because $d b / d b$ mice are known to exhibit hyperglycemia associated with obesity as early as 4 to 8 weeks after birth, ${ }^{88}$ and effects can be measured at 8 weeks after treatment. Therefore, the current study has advantages in its methodology.

A previous study reported different results under similar conditions to those in the current study. Bogdanov et $\mathrm{al}^{54}$ reported that total retinal, outer nuclear layer, and INL thicknesses were significantly decreased in the central and INL in the peripheral retinas of diabetic mice at 8 weeks compared with nondiabetic controls, which is not in agreement with this study's results. These differences may be due to weight or glucose concentrations at 8 weeks, which was the time point of mice sacrifice in this study. However, the results from the current study are more reasonable because INS and LIX showed similar neurosensory retinal layer thicknesses as $d b / d m$, whereas parts of the retinal layers of D-CON were significantly thicker than those of $d b / d m$, and these increased thicknesses were the result of retinal edema caused by inflammation.

\section{Conclusions}

In conclusion, neuroinflammation was significantly reduced in lixisenatide-treated retinas compared with untreated or 
even insulin-treated retinas of early type 2 diabetic mice, independent of hyperglycemia. The neuroprotective effects of lixisenatide treatment should be evaluated in the peripheral INL, and may improve the prognosis of the early type 2 DR.

\section{References}

1. Leibowitz G, Kaiser N, Cerasi E: Balancing needs and means: the dilemma of the beta-cell in the modern world. Diabetes Obes Metab 2009, 11 Suppl 4:1-9

2. Prentki M, Nolan CJ: Islet beta cell failure in type 2 diabetes. J Clin Invest 2006, 116:1802-1812

3. Pitocco D, Tesauro M, Alessandro R, Ghirlanda G, Cardillo C: Oxidative stress in diabetes: implications for vascular and other complications. Int J Mol Sci 2013, 14:21525-21550

4. Girach A, Vignati L: Diabetic microvascular complications-can the presence of one predict the development of another? J Diabetes Complications 2006, 20:228-237

5. Villarroel M, Ciudin A, Hernandez C, Simo R: Neurodegeneration: an early event of diabetic retinopathy. World J Diabetes 2010, 1: $57-64$

6. Antonetti DA, Klein R, Gardner TW: Diabetic retinopathy. N Engl J Med 2012, 366:1227-1239

7. Barber AJ, Gardner TW, Abcouwer SF: The significance of vascular and neural apoptosis to the pathology of diabetic retinopathy. Invest Ophthalmol Vis Sci 2011, 52:1156-1163

8. Patwari P, Higgins LJ, Chutkow WA, Yoshioka J, Lee RT: The interaction of thioredoxin with Txnip. Evidence for formation of a mixed disulfide by disulfide exchange. J Biol Chem 2006, 281: 21884-21891

9. Oslowski CM, Hara T, O’Sullivan-Murphy B, Kanekura K, Lu S, Hara M, Ishigaki S, Zhu LJ, Hayashi E, Hui ST, Greiner D, Kaufman RJ, Bortell R, Urano F: Thioredoxin-interacting protein mediates ER stress-induced beta cell death through initiation of the inflammasome. Cell Metab 2012, 16:265-273

10. Lerner AG, Upton JP, Praveen PV, Ghosh R, Nakagawa Y, Igbaria A, Shen S, Nguyen V, Backes BJ, Heiman M, Heintz N, Greengard P, Hui S, Tang Q, Trusina A, Oakes SA, Papa FR: IRE1alpha induces thioredoxin-interacting protein to activate the NLRP3 inflammasome and promote programmed cell death under irremediable ER stress. Cell Metab 2012, 16:250-264

11. Shalev A, Pise-Masison CA, Radonovich M, Hoffmann SC, Hirshberg B, Brady JN, Harlan DM: Oligonucleotide microarray analysis of intact human pancreatic islets: identification of glucoseresponsive genes and a highly regulated TGFbeta signaling pathway. Endocrinology 2002, 143:3695-3698

12. Perrone L, Devi TS, Hosoya K, Terasaki T, Singh LP: Thioredoxin interacting protein (TXNIP) induces inflammation through chromatin modification in retinal capillary endothelial cells under diabetic conditions. J Cell Physiol 2009, 221:262-272

13. Perrone L, Devi TS, Hosoya KI, Terasaki T, Singh LP: Inhibition of TXNIP expression in vivo blocks early pathologies of diabetic retinopathy. Cell Death Dis 2010, 1:e65

14. Singh LP: Thioredoxin interacting protein (TXNIP) and pathogenesis of diabetic retinopathy. J Clin Exp Ophthalmol 2013, 4. 10.4172/ 2155-9570.1000287

15. Wang XQ, Nigro P, World C, Fujiwara K, Yan C, Berk BC: Thioredoxin interacting protein promotes endothelial cell inflammation in response to disturbed flow by increasing leukocyte adhesion and repressing Kruppel-like factor 2. Circ Res 2012, 110:560-568

16. Go YM, Halvey PJ, Hansen JM, Reed M, Pohl J, Jones DP: Reactive aldehyde modification of thioredoxin-1 activates early steps of inflammation and cell adhesion. Am J Pathol 2007, 171:1670-1681
17. Schulze PC, Yoshioka J, Takahashi T, He Z, King GL, Lee RT: Hyperglycemia promotes oxidative stress through inhibition of thioredoxin function by thioredoxin-interacting protein. J Biol Chem 2004, 279:30369-30374

18. Dunn LL, Simpson PJ, Prosser HC, Lecce L, Yuen GS, Buckle A, Sieveking DP, Vanags LZ, Lim PR, Chow RW, Lam YT, Clayton Z, Bao S, Davies MJ, Stadler N, Celermajer DS, Stocker R, Bursill CA, Cooke JP, Ng MK: A critical role for thioredoxin-interacting protein in diabetes-related impairment of angiogenesis. Diabetes 2014, 63 675-687

19. Shaked M, Ketzinel-Gilad M, Ariav Y, Cerasi E, Kaiser N, Leibowitz G: Insulin counteracts glucotoxic effects by suppressing thioredoxin-interacting protein production in INS-1E beta cells and in Psammomys obesus pancreatic islets. Diabetologia 2009, 52:636-644

20. Chen J, Hui ST, Couto FM, Mungrue IN, Davis DB, Attie AD, Lusis AJ, Davis RA, Shalev A: Thioredoxin-interacting protein deficiency induces $\mathrm{Akt} / \mathrm{Bcl}-\mathrm{xL}$ signaling and pancreatic beta-cell mass and protects against diabetes. FASEB J 2008, 22:3581-3594

21. Chen J, Saxena G, Mungrue IN, Lusis AJ, Shalev A: Thioredoxininteracting protein: a critical link between glucose toxicity and betacell apoptosis. Diabetes 2008, 57:938-944

22. Saxena G, Chen J, Shalev A: Intracellular shuttling and mitochondrial function of thioredoxin-interacting protein. J Biol Chem 2010, 285: 3997-4005

23. Duan J, Du C, Shi Y, Liu D, Ma J: Thioredoxin-interacting protein deficiency ameliorates diabetic retinal angiogenesis. Int J Biochem Cell Biol 2018, 94:61-70

24. Minn AH, Hafele C, Shalev A: Thioredoxin-interacting protein is stimulated by glucose through a carbohydrate response element anc induces beta-cell apoptosis. Endocrinology 2005, 146:2397-2405

25. Parikh H, Carlsson E, Chutkow WA, Johansson LE, Storgaard H, Poulsen P, Saxena R, Ladd C, Schulze PC, Mazzini MJ, Jensen CB, Krook A, Bjornholm M, Tornqvist $\mathrm{H}$, Zierath JR, Ridderstrale M, Altshuler D, Lee RT, Vaag A, Groop LC, Mootha VK: TXNIP regulates peripheral glucose metabolism in humans. PLoS Med 2007, 4:e158

26. Hopkins DF, Cotton SJ, Williams G: Effective treatment of insulininduced edema using ephedrine. Diabetes Care 1993, 16: $1026-1028$

27. Juliusson PB, Bjerknes R, Sovik O, Kvistad PH: [Generalized edema following insulin treatment of newly diagnosed diabetes mellitus Norwegian. Tidsskr Nor Laegeforen 2001, 121:919-920

28. Mamoulakis D, Bitsori M, Galanakis E, Raissaki M, Kalmanti M: Insulin-induced oedema in children and adolescents. J Paediatr Child Health 2006, 42:655-657

29. Bixler GV, Vanguilder HD, Brucklacher RM, Kimball SR, Bronson SK, Freeman WM: Chronic insulin treatment of diabetes does not fully normalize alterations in the retinal transcriptome. BMC Med Genomics 2011, 4:40

30. The Diabetes Control and Complications Trial Research Group: Early worsening of diabetic retinopathy in the Diabetes Control and Complications Trial. Arch Ophthalmol 1998, 116:874-886

31. Chong CR, Chan WP, Nguyen TH, Liu S, Procter NE, Ngo DT, Sverdlov AL, Chirkov YY, Horowitz JD: Thioredoxin-interacting protein: pathophysiology and emerging pharmacotherapeutics in cardiovascular disease and diabetes. Cardiovasc Drugs Ther 2014, 28 $347-360$

32. Einbinder $\mathrm{Y}$, Ohana $\mathrm{M}$, Benchetrit $\mathrm{S}$, Zehavi $\mathrm{T}$, Nacasch $\mathrm{N}$, Bernheim J, Zitman-Gal T: Glucagon-like peptide-1 and vitamin D: anti-inflammatory response in diabetic kidney disease in $\mathrm{db} / \mathrm{db}$ mice and in cultured endothelial cells. Diabetes Metab Res Rev 2016, 32 805-815

33. Lee YS, Jun HS: Anti-diabetic actions of glucagon-like peptide-1 on pancreatic beta-cells. Metabolism 2014, 63:9-19

34. Shao W, Yu Z, Fantus IG, Jin T: Cyclic AMP signaling stimulates proteasome degradation of thioredoxin interacting protein (TxNIP) in pancreatic beta-cells. Cell Signal 2010, 22:1240-1246 
35. MacDonald PE, El-Kholy W, Riedel MJ, Salapatek AM, Light PE, Wheeler MB: The multiple actions of GLP-1 on the process of glucose-stimulated insulin secretion. Diabetes 2002, 51 Suppl 3: S434-S442

36. Harkavyi A, Abuirmeileh A, Lever R, Kingsbury AE, Biggs CS, Whitton PS: Glucagon-like peptide 1 receptor stimulation reverses key deficits in distinct rodent models of Parkinson's disease. J Neuroinflammation 2008, 5:19

37. Kim S, Moon M, Park S: Exendin-4 protects dopaminergic neurons by inhibition of microglial activation and matrix metalloproteinase-3 expression in an animal model of Parkinson's disease. J Endocrinol 2009, 202:431-439

38. Hernandez C, Bogdanov P, Corraliza L, Garcia-Ramirez M, SolaAdell C, Arranz JA, Arroba AI, Valverde AM, Simo R: Topical administration of GLP-1 receptor agonists prevents retinal neurodegeneration in experimental diabetes. Diabetes 2016, 65:172-187

39. Sugimoto M, Sasoh M, Ido M, Narushima C, Uji Y: Retinal nerve fiber layer decrease during glycemic control in type 2 diabetes. J Ophthalmol 2010, 2010:569215

40. Lee Y-E, Kim J-W, Lee EM, Ahn Y-B, Song K-H, Yoon K-H, Kim H-W, Park C-W, Li G, Liu Z, Ko S-H: Chronic resveratrol treatment protects pancreatic islets against oxidative stress in $\mathrm{db} / \mathrm{db}$ mice. PLoS One 2012, 7:e50412

41. [Lixisenatide (Lyxumia), subcutaneous] French. J Pharm Belg 2014, 2:57-59

42. Clinical Review Report: Lixisenatide (Adlyxine): (Sanofi-aventis Canada Inc). Ottawa, ON, Canada, Canadian Agency for Drugs and Technologies in Health, 2017

43. Thorkildsen C, Neve S, Larsen BD, Meier E, Petersen JS: Glucagonlike peptide 1 receptor agonist ZP10A increases insulin mRNA expression and prevents diabetic progression in $\mathrm{db} / \mathrm{db}$ mice. J Pharmacol Exp Ther 2003, 307:490-496

44. Committee for the Update of the Guide for the Care and Use of Laboratory AnimalsNational Research Council: Guide for the Care and Use of Laboratory Animals: Eighth Edition. Washington, DC, National Academies Press, 2011

45. Anlauf E, Derouiche A: Glutamine synthetase as an astrocytic marker: its cell type and vesicle localization. Front Endocrinol (Lausanne) 2013, 4:144

46. Germer A, Jahnke C, Mack A, Enzmann V, Reichenbach A: Modification of glutamine synthetase expression by mammalian Muller (glial) cells in retinal organ cultures. Neuroreport 1997, 8: 3067-3072

47. Clemenzi MN, Wellhauser L, Aljghami ME, Belsham DD: Tumour necrosis factor $\alpha$ induces neuroinflammation and insulin resistance in immortalised hypothalamic neurones through independent pathways. J Neuroendocrinol 2019, 31:e12678

48. Zhang J, Gao Z, Yin J, Quon MJ, Ye J: S6K directly phosphorylates IRS-1 on Ser-270 to promote insulin resistance in response to TNF(alpha) signaling through IKK2. J Biol Chem 2008, 283: 35375-35382

49. Devi TS, Lee I, Huttemann M, Kumar A, Nantwi KD, Singh LP: TXNIP links innate host defense mechanisms to oxidative stress and inflammation in retinal Muller glia under chronic hyperglycemia: implications for diabetic retinopathy. Exp Diabetes Res 2012, 2012: 438238

50. Devi TS, Hosoya K, Terasaki T, Singh LP: Critical role of TXNIP in oxidative stress, DNA damage and retinal pericyte apoptosis under high glucose: implications for diabetic retinopathy. Exp Cell Res 2013, 319:1001-1012

51. Gupta N, Mansoor S, Sharma A, Sapkal A, Sheth J, Falatoonzadeh P, Kuppermann B, Kenney M: Diabetic retinopathy and VEGF. Open Ophthalmol J 2013, 7:4-10

52. Tremolada G, Del Turco C, Lattanzio R, Maestroni S, Maestroni A, Bandello F, Zerbini G: The role of angiogenesis in the development of proliferative diabetic retinopathy: impact of intravitreal anti-VEGF treatment. Exp Diabetes Res 2012, 2012:728325
53. Battaglia Parodi M, Cicinelli MV, Rabiolo A, Pierro L, Bolognesi G, Bandello F: Vascular abnormalities in patients with Stargardt disease assessed with optical coherence tomography angiography. Br J Ophthalmol 2017, 101:780-785

54. Bogdanov P, Corraliza L, Villena JA, Carvalho AR, Garcia-Arumi J, Ramos D, Ruberte J, Simó R, Hernández C: The db/db mouse: a useful model for the study of diabetic retinal neurodegeneration. PLoS One 2014, 9:e97302

55. Panse M, Kluth O, Lorza-Gil E, Kaiser G, Mühlbauer E, Schürmann A, Häring HU, Ullrich S, Gerst F: Palmitate and insulin counteract glucose-induced thioredoxin interacting protein (TXNIP) expression in insulin secreting cells via distinct mechanisms. PLoS One 2018, 13:e0198016

56. Barber AJ, Nakamura M, Wolpert EB, Reiter CE, Seigel GM, Antonetti DA, Gardner TW: Insulin rescues retinal neurons from apoptosis by a phosphatidylinositol 3-kinase/Akt-mediated mechanism that reduces the activation of caspase-3. J Biol Chem 2001, 276: 32814-32821

57. Cai X, Li J, Wang M, She M, Tang Y, Li J, Li H, Hui H: GLP-1 treatment improves diabetic retinopathy by alleviating autophagy through GLP-1R-ERK1/2-HDAC6 signaling pathway. Int J Med Sci 2017, 14:1203-1212

58. Zhou J, Shen X, Lu Q, Zhang M: Thioredoxin-interacting protein (TXNIP) suppresses expression of glutamine synthetase by inducing oxidative stress in retinal muller glia under diabetic conditions. Med Sci Monit 2016, 22:1460-1466

59. Lieth E, LaNoue KF, Antonetti DA, Ratz M; The Penn State Retina Research Group: Diabetes reduces glutamate oxidation and glutamine synthesis in the retina. Exp Eye Res 2000, 70:723-730

60. Pang B, Zhou H, Kuang H: The potential benefits of glucagon-like peptide-1 receptor agonists for diabetic retinopathy. Peptides 2018, 100:123-126

61. Fadini GP, Sarangdhar M, Avogaro A: Glucagon-like peptide-1 receptor agonists are not associated with retinal adverse events in the FDA Adverse Event Reporting System. BMJ Open Diabetes Res Care 2018, 6:e000475

62. Ghosh A, Roy A, Liu X, Kordower JH, Mufson EJ, Hartley DM, Ghosh S, Mosley RL, Gendelman HE, Pahan K: Selective inhibition of NF-kappaB activation prevents dopaminergic neuronal loss in a mouse model of Parkinson's disease. Proc Natl Acad Sci U S A 2007, 104:18754-18759

63. Zhang F, Qian L, Flood PM, Shi JS, Hong JS, Gao HM: Inhibition of IkappaB kinase-beta protects dopamine neurons against lipopolysaccharide-induced neurotoxicity. J Pharmacol Exp Ther 2010, 333:822-833

64. Lee Y-S, Park M-S, Choung J-S, Kim S-S, Oh H-H, Choi C-S, Ha SY, Kang Y, Kim Y, Jun H-S: Glucagon-like peptide-1 inhibits adipose tissue macrophage infiltration and inflammation in an obese mouse model of diabetes. Diabetologia 2012, 55:2456-2468

65. Yang J, Ren J, Song J, Liu F, Wu C, Wang X, Gong L, Li W, Xiao F, Yan F, Hou X, Chen L: Glucagon-like peptide 1 regulates adipogenesis in 3T3-L1 preadipocytes. Int J Mol Med 2013, 31:1429-1435

66. Challa TD, Beaton N, Arnold M, Rudofsky G, Langhans W, Wolfrum C: Regulation of adipocyte formation by GLP-1/GLP-1R signaling. J Biol Chem 2012, 287:6421-6430

67. Reiter $\mathrm{CE}, \mathrm{Wu} \mathrm{X}$, Sandirasegarane L, Nakamura M, Gilbert KA, Singh RS, Fort PE, Antonetti DA, Gardner TW: Diabetes reduces basal retinal insulin receptor signaling: reversal with systemic and local insulin. Diabetes 2006, 55:1148-1156

68. Vuong L, Conley SM, Al-Ubaidi MR: Expression and role of p53 in the retina. Invest Ophthalmol Vis Sci 2012, 53:1362-1371

69. Henkes HE, Houtsmuller AJ: Fundus diabeticus. An evaluation of the preretinopathic stage. Am J Ophthalmol 1965, 60:662-670

70. Yonemura D: [An electrophysiological study on activities of neuronal and non-neuronal retinal elements in man with reference to its clinical application (author's transl)] Japanese. Nippon Ganka Gakkai Zasshi 1977, 81:1632-1665 
71. Holopigian K, Seiple W, Lorenzo M, Carr R: A comparison of photopic and scotopic electroretinographic changes in early diabetic retinopathy. Invest Ophthalmol Vis Sci 1992, 33: 2773-2780

72. Brindley GS: Responses to illumination recorded by microelectrodes from the frog's retina. J Physiol 1956, 134:360-384

73. Ogden TE: The oscillatory waves of the primate electroretinogram. Vis Res 1973, 13:1059-1074

74. Wachtmeister L, Dowling JE: The oscillatory potentials of the mudpuppy retina. Invest Ophthalmol Vis Sci 1978, 17:1176-1188

75. Speros P, Price J: Oscillatory potentials. History, techniques and potential use in the evaluation of disturbances of retinal circulation. Surv Ophthalmol 1981, 25:237-252

76. Frost-Larsen K, Larsen HW, Simonsen SE: Oscillatory potential and nyctometry in insulin-dependent diabetics. Acta Ophthalmol (Copenh) 1980, 58:879-888

77. Simonsen SE: The value of the oscillatory potential in selecting juvenile diabetics at risk of developing proliferative retinopathy. Acta Ophthalmol (Copenh) 1980, 58:865-878

78. Yonemura D, Aoki T, Tsuzuki K: Electroretinogram in diabetic retinopathy. Arch Ophthalmol 1962, 68:19-24

79. Bresnick GH, Palta M: Oscillatory potential amplitudes. Relation to severity of diabetic retinopathy. Arch Ophthalmol 1987, 105: 929-933

80. Fletcher EL, Downie LE, Ly A, Ward MM, Batcha AH, Puthussery T, Yee P, Hatzopoulos KM: A review of the role of glial cells in understanding retinal disease. Clin Exp Optom 2008, 91: $67-77$
81. Silva PS, Cavallerano JD, Haddad NM, Kwak H, Dyer KH, Omar AF, Shikari H, Aiello LM, Sun JK, Aiello LP: Peripheral lesions identified on ultrawide field imaging predict increased risk of diabetic retinopathy progression over 4 years. Ophthalmology 2015, 122:949-956

82. Silva PS, Cavallerano JD, Sun JK, Soliman AZ, Aiello LM, Aiello LP: Peripheral lesions identified by mydriatic ultrawide field imaging: distribution and potential impact on diabetic retinopathy severity. Ophthalmology 2013, 120:2587-2595

83. Yang Q, Xu Y, Xie P, Cheng H, Song Q, Su T, Yuan S, Liu Q: Retinal neurodegeneration in $\mathrm{db} / \mathrm{db}$ mice at the early period of diabetes. J Ophthalmol 2015, 2015:757412

84. Dhasmana R, Sah S, Gupta N: Study of retinal nerve fibre layer thickness in patients with diabetes mellitus using Fourier domain optical coherence tomography. J Clin Diagn Res 2016, 10: $\mathrm{NC} 05-\mathrm{NC} 9$

85. Chen X, Nie C, Gong Y, Zhang Y, Jin X, Wei S, Zhang M: Peripapillary retinal nerve fiber layer changes in preclinical diabetic retinopathy: a meta-analysis. PLoS One 2015, 10:e125919

86. Ma J, Zhang Y, Zhu T-P, Xu J: [Correlation of optic retinal nerve fiber layer thickness and visual function in patients with nonproliferative diabetic retinopathy] Chinese. Zhonghua Yan Ke Za Zhi 2013, 49:514-520

87. Chihara E, Matsuoka T, Ogura Y, Matsumura M: Retinal nerve fiber layer defect as an early manifestation of diabetic retinopathy. Ophthalmology 1993, 100:1147-1151

88. Kodama H, Fujita M, Yamaguchi I: Development of hyperglycaemia and insulin resistance in conscious genetically diabetic $(\mathrm{C} 57 \mathrm{BL} / \mathrm{KsJ}$ db/db) mice. Diabetologia 1994, 37:739-744 